\title{
The Griever as a Stranger. A Discussion
}

\author{
Blanka BÁLINT \\ Sapientia Hungarian University of Transylvania, Cluj-Napoca, Romania \\ balintblanka@uni.sapientia.ro
}

\begin{abstract}
The study is, in fact, an interpretation alternative that tries to identify a griever as a stranger in a previously familiar medium. This may refer to an inner strangeness when the griever discovers a kind of strangeness in his or her relationship with himself or herself that questions his or her earlier identity or a feeling of strangeness in relation to friends and acquaintances. In the systematization of the feeling of strangeness in relation to others, I used Schütz's "homecomer" model of a returning veteran as a starting point. This approach brings us closer to understanding the difficulties of relating to grievers.
\end{abstract}

Keywords: grief, stranger, homecomer, social relationships, posttraumatic growth

\section{Introduction}

“A stranger is a friend I haven't met yet”-says Marge Deton in Dan Buettner's TED presentation. ${ }^{1}$ In my study, I am searching for an answer to the opposite situation: can a griever become a stranger among his or her friends?

The rationale is that the identification of the griever as a stranger may be a suitable narrative to understand the difficulties of relating to grievers. At the same time, this approach may be an opportunity to improve the daily interactions of grievers; in case the formerly known individual suddenly appears as out of ordinary, in this new situation, it will become necessary to develop a new kind of approach. In this sense, based on this experiment of interpretation, new solutions may be developed to an old problem (the isolation experienced by a significant part of grievers), which take into account the special difficulties of grievers as a vulnerable group. ${ }^{2}$

1 https://www.ted.com/talks/dan_buettner_how_to_live_to_be_100.

2 According to Pilling's (2012) research results, the period of mourning is a vulnerable state in which certain somatic and mental complaints appear more frequently. 
In answering the central question of the study, it is necessary to first clarify the notions of "griever" and "stranger". This is followed by the presentation of the griever's strangeness, which is closed by a summary.

\section{The definitions of "griever" and "stranger"}

Grief is a well-known concept; we all went through grief in some form or another, ${ }^{3}$ and yet it is difficult to define the term. Not even in specialized literature is there a complete agreement regarding the use of the concept.

When defining grief, the majority of definitions highlight the reactions that follow the loss of a beloved person: Freud (1917), Parkes (1988-quoted by Vizinger 2010), Polcz (1997), or Makai (2012). Another group of authors approach the definition of grief in a broader sense, as types of reaction to a stressful life situation (Lindemann 1998), a very significant value (Verena Kast 1999), a trauma (Németh 2000), a loss (Pilling 2012), or a life change (James \& Friedman 2011quoted by Sarungi \& Herke Dahlgren 2012).

Based upon the above, we can affirm that several kinds of losses (such as losing a job, losing the idealistic image of a healthy child when a handicapped child is born, losing a beloved person because of a move to another continent, divorce, etc.) can trigger a reaction of grief. Out of all of these, usually the death of a beloved relative causes the most intense reaction. ${ }^{4}$ From this starting point, in our study, we will use the concept of grief as the variety of reactions and behavior patterns following the death of a beloved person ${ }^{5}$ (or a pre-shadowed death) ${ }^{6}$; the griever is the person who goes through grief.

The other question is what the concept of stranger means. Who counts as a stranger? Somebody who speaks a different language, belongs to another culture or another group, has a different set of beliefs, or is simply different? Being a stranger might mean a different religion or a different language or physical strangeness; at the same time, we may experience the stranger within us as well (Czirkos 2011). Descriptions of the concept of strangeness prove that the essence of the notion of a stranger is impossible to define; as Nyíró (2005) remarks, the studies included in The Stranger-Variations from Simmel To Derrida (Idegen - Variációk Simmeltól Derridáig—Biczó 2004) are an ample proof of this fact.

3 According to Viorst (1986), we begin our life with a loss, as we lose the safety of the womb.

4 Relying on the results of research, Magdolna Singer claims that losing a spouse through divorce involves even more suffering than a loss through death (Singer 2010).

5 To me, life begins with conception; therefore, the loss of a fetus via spontaneous or induced abortion is included in this category.

6 The appearance of the possibility of death (such as an incurable tumor detected in a relative) may trigger feelings of grief identical to an actual death. In literature, this is called anticipatory grief (Lindemann 1998). 
There is, however, a consensus in the fact that we cannot talk about a unified approach to this issue, as the outstanding German phenomenologist Bernhard Waldenfels puts it (Waldenfels 2004: 110).

In approaching strangeness, Waldenfels' approach has offered me a starting point. According to Waldenfels, strangeness is not limited to the strangeness of other cultures (Waldenfels 2004: 116); at the same time, strangeness is always defined by the here and now. This means that even a grieving friend may trigger an experience of strangeness. Besides, I can experience a friend as a stranger if I am the one who grieves, if that friend has never had to cope with a similar loss. In Waldenfels' words, a threshold divides the stranger from the eternal selfhood; at the same time, we can never stand on both sides of the threshold (Waldenfels 1996). Being a stranger is always the result of a simultaneous delimitation and exclusion; therefore, it cannot be disguised from the point of view of an impartial third party. To conclude, the stranger does not exist as such, and we can speak only about different forms of strangeness (Waldenfels 1996). Distance and unapproachability, in fact, are also a part of strangeness, meaning that the stranger is defined as being in another place, as a person who is never entirely in his or her place (Waldenfels 1996).

\section{Strangeness linked to grief}

Strangeness does not start outside of us, but within us; this phenomenon is the socalled intra-subjectivity (Waldenfels 1996). In the relationships with others, but also in the relationship with my own self, I can discover a stranger-like quality that questions my self-identity (Tengelyi 1998). One of the examples of this phenomenon is the griever discovering negative feelings within himself or herself that are difficult to accept as part of his or her identity. For example, anger can be a powerful presence during the course of grief; grievers search for someone to blame, someone who is responsible for the death that has occurred. The target of anger can be the healthcare personnel, the doctor, and the deceased or the griever can even blame himself or herself for the death of a relative (Kast 1999). Anger can also be manifested against God because he allowed or did not prevent death (Pilling 2012). ${ }^{7}$ Besides anger, another example is unpredictable irritability (Lindemann 1988) or hatred and envy towards mothers and babies in the case of women who suffered perinatal loss (Singer 2008); such reactions are also a natural part of the course of grief.

In the relationship with the Other, in my opinion, the griever is similar to Schütz's "homecomer"' (Schütz 2004) who feels that he or she has arrived among

7 I have often experienced these when counselling grievers.

8 A typical example is that of the homecoming veteran's, but it can also be the traveler returning from abroad, the immigrant returning to his or her native country, or the youth who made a good living in a foreign country and now returns to settle down in his or her hometown (Schütz 2004). 
strangers as long as "the goddess does not disperse the fog lingering around him or her" (Schütz 2004: 80). According to Schütz (2004), the homecomer-in this case, the griever-expects to come back to a well-known environment; however, we will see that this is not the case: the griever, on the one hand, loses the sense of "homeyness", and, on the other hand, a distance is created in his or her social relationships. At the same time, it becomes difficult to restore social relationships, and actually the griever himself or herself also changes. Hereinafter, I will go into more details regarding these aspects.

The loss of sense of homeyness means the uncertainty of everyday selfexplanatory concepts, as nowadays the habits and traditions that helped the griever in enduring the pain and reorganizing life have been partly lost or have become void of their meaning (Buda 1997, Polcz 1997, Pilling 2012, Singer 2010). ${ }^{9}$ These traditions and customs used to provide the griever with community support, on the one hand, and serve as a pattern of behavior helping the griever to pursue daily life, on the other hand. Earlier, knowledge to aid the processing of grieving was passed on by one generation to the other, but today we can mostly learn it from books, literature, and courses (Polcz 2005). Therefore, there is no canonized knowledge that would serve as a guide after the loss of a loved one. Instead, a number of new habits are emerging, such as virtual candle lighting, mourning rooms, creation of memorial webpages, conversion of social network profile pages to memorial sites, etc., which all offer new ways of processing grieving. Thus, the old proven tools have weakened, and the newly emerging rites have not yet spread and become accepted by entire local communities. As a result, the griever may easily lose the feeling of "homeyness".

As a result of grieving, a distance may form in relationships as well. ${ }^{10}$ Relationships involve a common horizon, on which the common orientation and the objects of relevance are situated (Schütz 2004). However, a change occurs in this respect if a person leaves his or her home and moves to a different social dimension. Along with a change of the environment, different things become important for the two persons in a relationship (Schütz 2004: 85). A similar situation may also be observed in the relationships between the griever and his or her environment. In the changed situation, the griever does not necessarily find formerly important things-that is, things that used to be important before the occurrence of the loss-still important. (The range may include anything and everything from dilemmas on the lines of "where should we go on the weekend?"

9 These processes are described by the authors mainly in the Hungarian context, but similar processes occur in our region as well, mainly in urban environments. Rural settlements have retained more traditions, such as prayer (among the Catholic population), wake (among the Reformed community), or the burial feast (a community meal), but these have also become formalized. The tendency of institutionalization (Polcz 2005) is evident in our region as well.

10 Several authors have mentioned the difficulties of maintaining a loving relationship with others-e.g. Lindemann (1988). 
to problems at the workplace.) As a result of the changes in the griever's priorities, the common orientation disappears. This change in the reference system therefore changes the degree of "reliable knowledge" regarding the other person and the relationship (Schütz 2004).

The restoration of a relationship broken due to grieving is difficult because the mourners' environment cannot directly experience the griever's feelings after the loss. Grief is always unique, just as every relationship is unique (Sarungi \& Herke Dahlgren 2012). The Other may possess knowledge about grief, may read about it, may watch movies related to it, but all these are stereotypes of grief and not the griever's individual and unique experiences, as described by Schütz (2004) in relation to the experiences of a soldier on the battlefield. According to Schütz, no proof exists that situations presented as typical are also relevant for an absent member of an own group. Moreover, when such a person goes home and starts talking, he or she is surprised to realize that those who remained at home do not understand the uniqueness of his or her individual experiences; instead, they try to isolate familiar elements in what they hear, and attach these to previously shaped types.

The griever can have a similar experience; it needs to be mentioned, however, that these so-called "known types" are not of a unified character either. In the literature on grief, not only the definitions of grief show a wide range of variety but also the distinguishing of the various stages of a typical grieving process. The initial models distinguished three stages: the phase of the emotional shock, the phase of developing awareness, and the phase of recovery and restitution (Engel 1964, Averill 1968-quoted by Pilling 2012). Better-known models, such as Kübler-Ross (1988) or Kast (1999), distinguish five stages. Kübler-Ross (1988) developed these stages based upon conversations with dying persons, and the stages refer to the journey towards death; nevertheless, in specialized literature, they are regarded as phases of grief. János Pilling (2012) adds anticipatory ${ }^{11}$ grief to the five phases he has defined.

The majority of experts studying grief agree that the news of having lost a beloved person is experienced as a shock by most people. Instead of a state of shock, Alaine Polcz (2005) uses the expression of "facing"; according to her, shock is simply a kind of reaction, whereas a meeting can also be a quiet and helpful acceptance, especially if the ritual of dying has prepared us to face it. ${ }^{12}$ According to the above, it is obvious that the models do not only differ in the number of stages but also in the designation of stages and their content (in the

11 Anticipatory grief is when mourning begins before the death occurs. This usually makes it easier to endure the actual occurrence of death, but occasionally it may make the processing of grief more difficult if there is a strong bond between the dying and the grieving person (Zisook 1995qtd. in Pilling 2012).

12 During conversations with grievers, I often saw silent acceptance, especially in anticipatory mourning. 
Hungarian context, cf. Polcz 2005 and Pilling 2012). Beyond the division of the stages of grief, there are also authors who deny the existence of phases and call the attention on the uniqueness of the grieving process (Friedman 2008-qtd. in Sarungi \& Herke Dahlgren 2012).

The multi-faceted character of the typical grief phases accepted in literature signifies the discrepancy between the so-called "typical" and the uniqueness experienced by grievers. This, according to Schütz (2004), is one of the greatest obstacles in the way of restoring broken relationships; the complexity of the issue is even more accentuated if we take into consideration the reactions of grief that differ from the usual, ${ }^{13}$ disenfranchised grief ${ }^{14}$ or gender differences in processing grief (Cook 1988).

A person experiencing grief may also change as his or her previous experiences are re-evaluated and given a new interpretation in the light of the newly acquired experiences (Schütz 2004). In the literature on grief, this phenomenon is called posttraumatic growth, signifying a positive change that occurs as a result of a struggle in a very stressful life situation (Tedeschi \& Calhoun 1996). ${ }^{15}$ Posttraumatic growth can be manifested in various forms such as placing a higher value on life, experiencing more significant relationships, the increase of inner strength, the change of priorities, and richer existential and spiritual life (Tedeschi \& Calhoun 2004). The authors acknowledge the possible negative consequences involved in such a life-style, but they also draw attention to the positive changes resulting from stressful life situations. Growth does not only mean a change that occurs as a direct consequence of a trauma but also the result of the spiritual battle following the trauma. In this sense, posttraumatic growth does not only mean a return to a previous state but also growth that represents a deep and lasting change for many (Tedeschi \& Calhoun 2004).

13 In order to avoid stigmatization, in accordance with Wolfet's (1991) suggestion, these reactions are commonly referred to as complicated grief, but the meaning of the notion is still controversial (cited in Pilling 2012). Deviation from the typical can be grasped in the duration of mourning (chronic mourning) and the intensity of emotions (minimizing, hypertrophic mourning).

14 In the case of disenfranchised grief, society does not consider grief a legitimate one (Doka 2002-qtd. in Attig 2004). This may be due to the nature of the relationship when the deceased and the survivor are not connected by a traditional relationship (e.g. homosexual relationship, extramarital relationship), but it may also include the loss in case of denial of the significance of the loss (e.g. abortion, perinatal mortality, death of a prison inmate, etc.). The notion of disenfranchised grief may also refer to grievers when the ability of certain groups for grieving (such as children, the elderly, persons with mental disabilities) is not acknowledged (Doka 1989-qtd. in Attig 2004). In his later work, Doka (2002) defines two more categories to which the term disenfranchised can be applied: one of these is the circumstances of death (e.g. suicide, death by stigmatized illnesses, executions, etc.) and the other is the way in which people grieve if the process is in conflict with the community's expectations (qtd. in Attig 2004).

15 Painfully beautiful examples of posttraumatic personality development following perinatal loss can be found in Singer's (2009) study. 


\section{Conclusions}

The main question of the study focuses on the grievers' sense of strangeness. This, on the one hand, may mean inner strangeness when the griever discovers a kind of strangeness in his or her relationship with himself or herself that questions his or her earlier identity or, as Montaigne (2001) states it: the griever becomes the strangest to himself or herself in the intimacy of self-observation (qtd. in Schlesier 2004: 41).

On the other hand, the notion may represent a feeling of strangeness towards friends and acquaintances as well, the understanding of which is facilitated by the "homecomer" model developed by Schütz. Based on this, it can be said that losing a loved one may mean that some of the everyday, self-explanatory knowledge suddenly becomes insufficient; therefore, new patterns and practices become necessary, and as a result the griever may lose the sense of homeyness. In addition, the griever's social relations change, as the change in the priorities of the griever involves the dissolution of the common reference system. The changed relationship will be difficult to restore, the greatest obstacle being the experienced uniqueness and the typical in-between break. As a result of grieving, the griever himself or herself may also change. This distancing hides the mourner behind a "strange mask" (Schütz 2004: 85). This way, the griever may become a stranger in his or her own surroundings.

\section{References}

Attig, Thomas. 2004. Disenfranchised Grief Revisited: Discounting Hope and Love. Omega 49: 197-215. (https://www.ualberta.ca/ jennyy/PDFs/14022506. pdf; last visit on: March 19, 2017).

Balogh, Éva. 1999. „A bánat bálnája” (Párterápia gyászban) [A Whale of Sadness - Couple Therapy in Mourning]. Kharón Thanatológiai Szemle III./autumn.

Biczó, Gábor (ed.). 2004. Az Idegen - Variációk Simmeltól Derridáig. [The Stranger-Variations from Simmel to Derrida]. Debrecen: Csokonai Press.

Buda, Béla. 1997. A halál és a haldoklás szociálpszichológiai tényezői és folyamatai [Socio-Psychological Factors and Processes of Death and Dying]. Kharón Thanatológiai Szemle. II./winter.

Cook, Judith A. 1988. Dad's Double Binds: Rethinking Fathers' Bereavement from a Men's Studies Perspective. Journal of Contemporary Ethnography 17: 284-308. Czirkos, Eszter. 2011. Szembesülni azzal, ami idegen [Facing That Which Is Strange]. Fordulat 2: 131-142. 
Farkas, Lőrinczné. 1999. Az elszakadás és megtartás integrációjának nehézségei. In: Németh, Tünde, Nyíri, Magdolna (eds.), Gyász a szeretetben és a családban [Mourning in Love and in the Family]. Budapest: NEVI.

Freud, Sigmund. 1917. Mourning and Melancholia. In: The Standard Edition of the Complete Psychological Works of Sigmund Freud. London: The Hogarth Press. (http://www.scribd.com/doc/27577137/Freud-Mourning-and-Melancholia-1917; last visit on: August 25, 2016).

Kast, Verena. 1999. A gyász. Egy lelki folyamat stádiumai és esélyei. Budapest: Park Press. Transl. by Mérei, Vera. [Original title: Trauern: Phasen und Chancen des psychischen].

Kübler-Ross, Elizabeth. 1988. A halál és a hozzá vezetô út. Budapest: Gondolat. Transl. by Blasszauer, Béla. [Original title: On Death and Dying: What the Dying Have to Teach Doctors, Nurses, Clergy and Their Own Families].

Lindemann, Erich. 1998. Az akut gyász tünettana és kezelése. Kharón Thanatológiai Szemle II./winter [Original title: Symptomatology and Management of Acute Grief].

Makai, Nóra Csilla. 2012. A normál és a komplikált gyászhoz kötődő viselkedésformák, valamint a támogató lehetőségek megítélése [Judging Behavior Patterns Related to Typical and Complicated Grief and Possibilities of Support]. Kharón Thanatológiai Szemle XVI(3): 1-34.

Németh, Tünde. 2000. A szeretet hídján. Veszteségélmények feldolgozása egy speciális életciklusban, a várandósság idején [On the Bridge of Love. Processing Experiences of Loss in a Special Life Cycle, During Pregnancy]. Kharón Thanatológiai Szemle IV./summer.

Nyírő, Miklós. 2005. Szemle: Az Idegen - variációk Simmeltől Derridáig [The Stranger-Variations from Simmel to Derrida]. BUKSZ. 272-277.

Polcz, Alaine. 1997. Együtt a halálban és a gyászban [Together in Death and Grief]. Kharón Thanatológiai Szemle I./winter.

2005. Együtt az eltávozottal [Together with the Departed]. Pécs: Jelenkor Press. Pilling, János. 2012. A gyász hatása a testi és lelki egészségi állapotra. Doktori értekezés [The Effect of Grieving on the Physical and Mental State. PhD Thesis]. Budapest: Semmelweis Egyetem. Mentális Egészségtudományok Doktori Iskola.

Sarungi, Emőke, Herke Dahlgren, Andrea. 2012. Gyógyulás a gyászból - Módszerismertetetés [Recovery from Grief-Presentation of Methodology). Kharón Thanatológiai Szemle XIV(1-2): 19-32.

Schütz, Alfred. 2004. A hazatérő [Original title: The Homecomer]. In: Biczó, Gábor (ed.), Az Idegen - Variációk Simmeltól Derridáig. 80-90. Debrecen: Csokonai Press.

Schlesier, Renate. 2004. A vén Európa az Újvilág tükrében. Montaigne és az „emberevők” [Original title: Alteuropaim Spiegel derneuen Welt. Montaigne 
und die “Kannibalen”]. In: Biczó, Gábor (ed.), Az Idegen - Variációk Simmeltól Derridáig. 30-41. Debrecen: Csokonai Press.

Singer, Magdolna. 2008. Áldatlan állapot. Mi lesz velünk? [Non-Expectancy. What Will Become of Us?] Budapest: Jaffa Press.

2009. Jöttem is, meg nem is, hoztam is, meg nem is... Poszttraumás személyiségfejlődés perinatális gyász esetében [I Came and I Did Not, I Brought and I Did Not... Posttraumatic Personality Development in Perinatal Grief). KharónThanatológiai Szemle XIII(2): 55-71.

2010. Vigasztalódás a gyászban [Consolation in Mourning]. Budapest: Jaffa Press.

Tengelyi, László. 1998. Élettörténet és sorsesemény [Story of Life and Event of Destiny]. Budapest: Atlantisz Publishing House.

Viorst, Judith. 2002. Szükséges veszteségeink. Budapest: HáttérPress. Transl. by Horváth, Krisztina [Original title: Necessary Losses].

Vizinger, Erzsébet. 2010. Gyász és autogén tréning [Grief and Autogenic Training]. Kharón Thanatológiai Szemle XIV(1): 1-46.

Waldenfels, Bernhard. 1996. Felelet arra, ami idegen. Egy reszponziv fenomenológia vázlata. (http://www.c3.hu/ gond/tartalom/20/frawald.html; last visit on: November 12, 2016). [Original title: Responsive Phenomenology of the Alien: an Introduction].

2004. Az idegenség etnográfiai ábrázolásának paradoxonjai. In: Biczó, Gábor (ed.), Az Idegen - Variációk Simmeltól Derridáig. 91-116. Debrecen: Csokonai Press. [Original title: Paradoxien ethnographischer Fremddarstellung]. 